E3S Web of Conferences 1, 06006 (2013)

DOI: $10.1051 / \mathrm{e} 3$ sconf/20130106006

(C) Owned by the authors, published by EDP Sciences, 2013

\title{
Heavy metals in sediments and halophytes of saltmarshes in the Marano and Grado Lagoon (Northern Adriatic Sea)
}

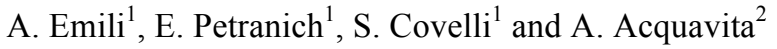 \\ ${ }^{1}$ Dipartimento di Matematica \& Geoscienze, Università di Trieste, Via Weiss 2, 34128 Trieste (Italy), \\ andemili@gmail.com, covelli@units.it \\ ${ }^{2}$ Osservatorio Alto Adriatico, Agenzia Regionale per la Protezione dell'Ambiente del Friuli Venezia Giulia \\ (ARPA-FVG), Via Cairoli 14, 33057, Palmanova (Italy), acquavitaa@arpa.fvg.it
}

\begin{abstract}
The content of several heavy metals ( $\mathrm{As}, \mathrm{Cd}, \mathrm{Cr}, \mathrm{Cu}, \mathrm{Hg}, \mathrm{Mn}, \mathrm{Ni}, \mathrm{Pb}, \mathrm{Zn}$ ) was determined in sediments and in plants (the halophytes Sarcocornia fruticosa and Limonium vulgare) from two selected saltmarshes located in the Marano and Grado Lagoon (Northern Adriatic Sea). This environment has been affected by severe $\mathrm{Hg}$ contamination from both industrial and long-term mining activities. In both saltmarshes, $\mathrm{Hg}$ content in sediments exceeded the estimated background value $\left(0.13 \mu \mathrm{g} \mathrm{g}^{-1}\right)$, showing the highest concentrations (13.7 $\mu \mathrm{g} \mathrm{g}^{-1}$ ) in the eastern sector (Grado Lagoon), the most affected by cinnabar ore extraction. On the other hand, the saltmarsh, located in the Marano Lagoon, showed a higher degree of contamination for $\mathrm{As}, \mathrm{Cd}$ and $\mathrm{Pb}$, which can be related to industrial sources. The rhizo-sediments of both halophytes reflected the characteristics of the non-vegetated sediment, with higher organic carbon content and similar metal concentrations. Enrichment Factors $\left(E F=[\text { metal }]_{\text {root }} /[\text { metal }]_{\text {rhizo-sediment }}\right)$ for each sediment layer were calculated for both halophytes, showing metal enrichments in the roots and the presence of preferential layers of metal accumulation. Hg showed accumulation (EF>1) in the roots below the $20 \mathrm{~cm}$ depth, with higher contents in $S$. Fruticosa. As and Cd were accumulated by both halophytes, more efficiently by $S$. Fruticosa, and the same species showed also accumulation of $\mathrm{Pb}$ and $\mathrm{Zn}$. Translocation of metals from the roots to the aboveground biomass was investigated by measuring metal contents in shoots and leaves of the two species. With the exception of $\mathrm{Cd}$ and $\mathrm{Hg}$, all metals were present in the aboveground biomass, most evidently for $\mathrm{Cr}$ in $S$. Fruticosa and $\mathrm{Zn}$ in L. Vulgare, although the presence of the latter in leaves could be due to plant physiology rather than translocation of the contaminant.
\end{abstract}

Key words: Saltmarshes, heavy metals, halophytes, bioaccumulation, enrichment factor

\section{Introduction}

Saltmarshes are important constituents of transitional environments, where they provide several services to the ecosystem and are essential to the sedimentary budget (Pethick, 1984). On the other hand, these peculiar environments are also subject to the effects of increasing human pressure, especially where anthropogenic activities occur. As a consequence, sediments trapped by the saltmarsh vegetation may be affected by the accumulation of several contaminants, heavy metals included (Cacador et al., 1996).

Plants living in saltmarshes show specific adaptations to these hypersaline environments (Breckle, 2002). A common characteristic is their ability to accumulate heavy metals both in roots and shoots (Cacador et al, 2009; Canario et al., 2010). In this manner, they act as hyper accumulators, thus providing a natural metal-extraction pathway for remediation activities.

The Marano and Grado Lagoon (Northern Adriatic Sea) is the second largest lagoon area of the Adriatic after Venice. The Lagoon is generally considered a well-preserved area where conservation of the natural environment must coexist with several human activities such as fishing, shipping and industries.

The main source of contamination in the Lagoon is represented by the inflow from the Aussa-Corno river system which is impacted by industrial discharges from several industries and is connected to the open sea by a navigable channel. Another source of contamination is the Isonzo River, the largest contributor of mercury into the northern Adriatic Sea since the 16th century, due to its transport of cinnabar $(\mathrm{HgS})$ rich tailings from the Idrija (Slovenia) mining district (Covelli et al., 2001). 

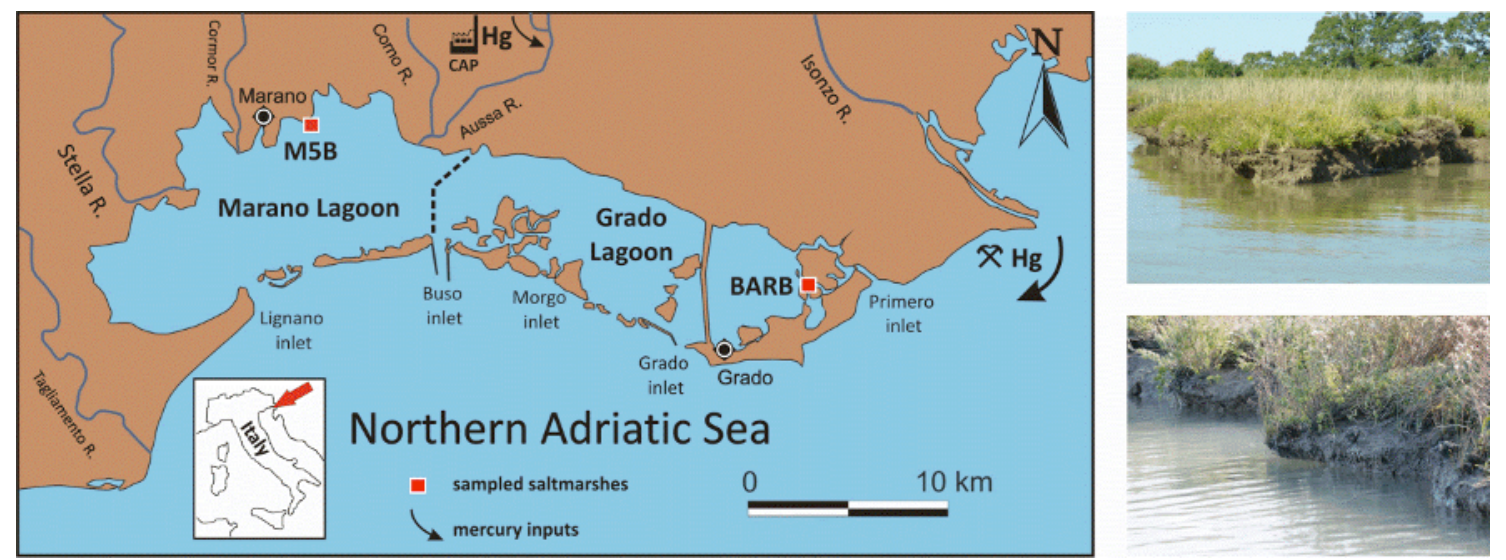

Fig. 1. Location of the sampled saltmarshes in the Marano and Grado Lagoon (Northern Adriatic): M5B (Marano Lagoon) and BARB (Grado Lagoon). The black arrows indicate $\mathrm{Hg}$ inputs from the Isonzo and Aussa-Corno rivers.

The aim of this study was to evaluate the content of several heavy metals (As, $\mathrm{Cd}, \mathrm{Cr}, \mathrm{Cu}, \mathrm{Hg}, \mathrm{Mn}, \mathrm{Ni}, \mathrm{Pb}$, $\mathrm{Zn})$ in sediments and in plants from two selected saltmarshes located in the Lagoon. Enrichment Factors (EF) and metal translocation from the belowground to the aboveground biomass were also considered.

\section{Materials and Methods}

Sampling operations took place in July 2011. Two saltmarshes were investigated: M5B in the Marano Lagoon and BARB in the Grado Lagoon (Fig. 1). The saltmarshes differ for morphology and heavy metal contents and are representative of a highly impacted area (Marano Lagoon) and a moderately (except for high $\mathrm{Hg}$ contents) contaminated area (Grado Lagoon).

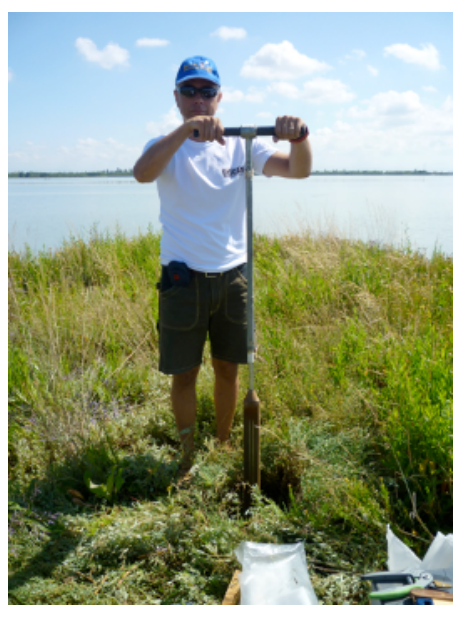

Fig. 2. The hand-corer used for sediment and belowground biomass sampling.

In both saltmarshes, individuals of Sarcocornia Fruticosa and Limonium Vulgare, two of the most abundant halophytes in this environment, were considered. The aboveground biomass (shoots and leaves) was collected and sealed in plastic bags. In correspondance to the severed shoots, the belowground biomass and the attached rhizo-sediment were sampled using a 5.5 by $50 \mathrm{~cm}$ hand-corer (Fig. 2).

The obtained sediment cores (including roots) were sectioned on field (Fig. 3) into 9 depth levels: every $2 \mathrm{~cm}$ in the first $10 \mathrm{~cm}$ and then into $5 \mathrm{~cm}$ slices to a maximum depth of $30 \mathrm{~cm}$.

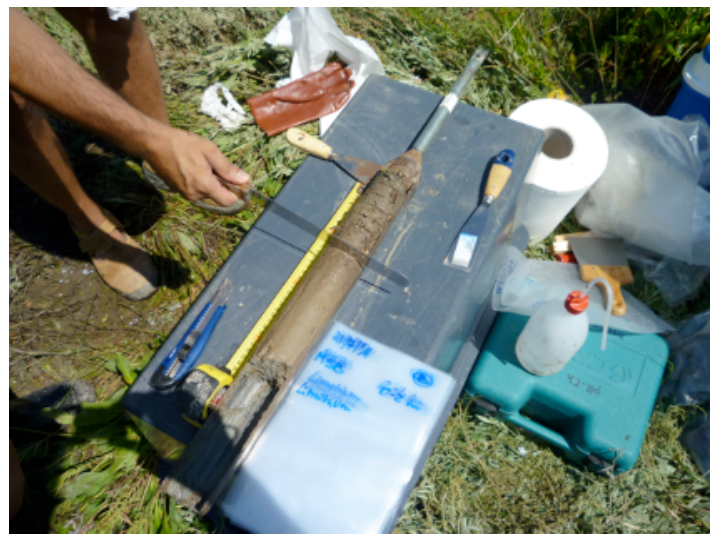

Fig. 3. Core slicing and subsampling.

In the laboratory, roots were carefully separated from the rhizo-sediment, washed with distilled water and thoroughfully rinsed with Milli-Q water. Sediment, roots, leaves and shoots were freeze-dried, finely ground and homogenized. The obtained samples were totally decomposed (Loring and Rantala, 1992) using a mixture of mineral acids in a closed microwave system (Milestone MLS 1200), as required by the different procedures. The obtained solutions were analyzed for heavy metal content by ICP-AES. Total $\mathrm{Hg}$ content in the solid-phase was determined by DMA-80 (Milestone).

\section{Results and Discussion}

The heavy metal content in the sediments was quite high at both saltmarshes. Compared to local background levels, M5B was the most contaminated site, with higher values especially for $\mathrm{As}, \mathrm{Cd}$, and $\mathrm{Pb}$. On the other hand, $\mathrm{Cu}$ and $\mathrm{Hg}$ were highest in BARB. Such results reflect the different contamination history of the two areas: M5B is directly influenced by the industrial area that insists on the Marano basin, while BARB is subject to 
contamination by the $\mathrm{Hg}$-rich particulate matter inflowing from the Isonzo River.

To evaluate metal accumulation in the plants, the Enrichment Factors $\left(\mathrm{EF}=[\text { metal }]_{\text {roots }} /[\text { metal }]_{\text {rhizo-sediment }}\right)$ were calculated. In both saltmarshes, the halophyte
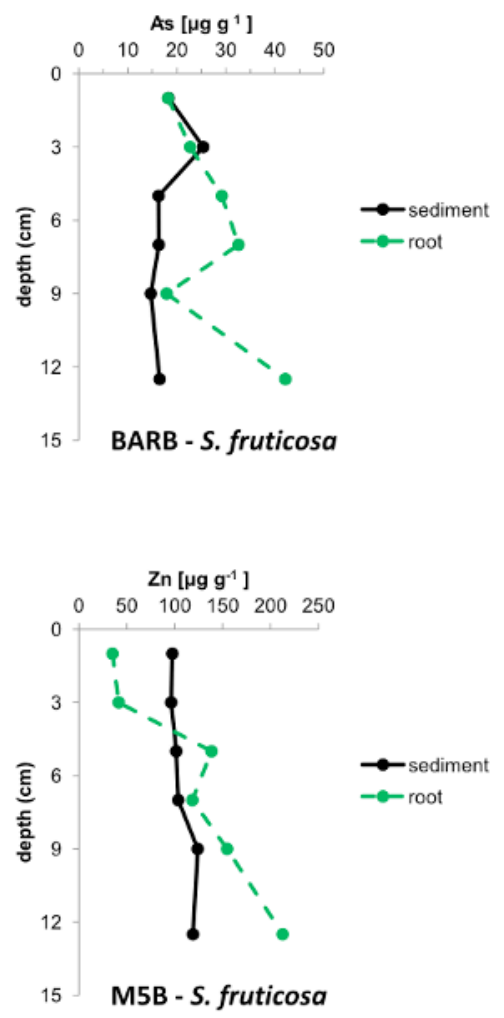

vegetation showed accumulation $(\mathrm{EF}>1)$ of $\mathrm{As}$ and $\mathrm{Cd}$, but not of Ni (Fig. 4). $S$.fruticosa showed the greater bioaccumulation while M5B seemed to be a more favorable site for such processes, probably due to redox conditions in the sediment that enhance metal mobility.
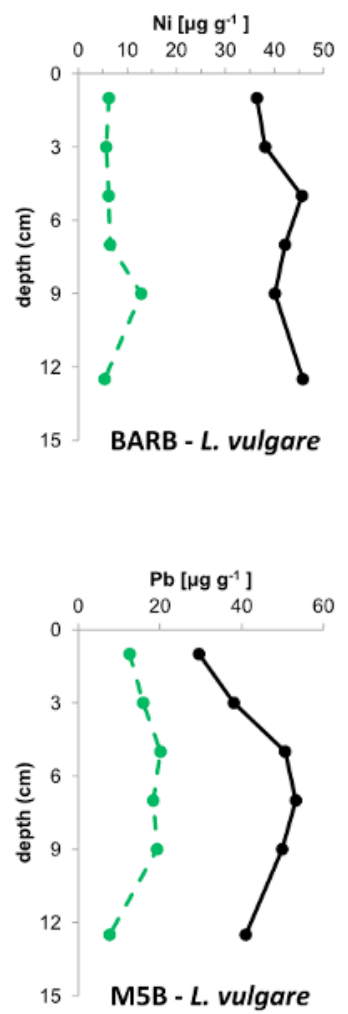

Fig. 4. Vertical concentration profiles for $\mathrm{As}, \mathrm{Ni}, \mathrm{Zn}$, and $\mathrm{Pb}$ in sediments (continuous line) and roots (dashed line) of the halophytes S. fruticosa and L. vulgare in the Marano and Grado Lagoon saltmarshes (sites M5B and BARB).

The translocation of metals from the halophytes' roots to their shoots and leaves was evident at both saltmarshes. Notably, at BARB, $\mathrm{Cr}$ in the shoot of $S$. fruticosa was

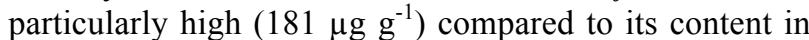
the roots $\left(69 \mu \mathrm{g} \mathrm{g}^{-1}\right)$ and rhizo-sediment $\left(86 \mu \mathrm{g} \mathrm{g}^{-1}\right)$. In $L$. vulgare, the $\mathrm{Zn}$ content in the leaves was almost double of that in the shoots and about a half of that in the roots. $\mathrm{Zn}$ is an essential element for plant physiology, playing a key role as enzymatic co-factor and, thus, its presence in the leaves is not surprising. No translocation was observed for $\mathrm{Cd}$ and $\mathrm{Hg}$, and they appeared to be immobilized in the halophytes' roots

\section{Conclusions}

The present study is the first attempt to investigate heavy metal content in the sediments and vegetation of the Marano and Grado Lagoon saltmarshes. The results showed that these areas can be considered as a sink (and a possible source) for several heavy metals. Halophytes showed the ability to absorb metals from the saltmarsh sediment and to accumulate them in the roots and/or translocate them to the aboveground biomass. Bioaccumulation varied with the species and the different environmental conditions, showing the highest efficiencies in $\mathrm{S}$. fruticosa and in the industrially-impacted Marano basin.

\section{Acknowledgements}

The authors would like to thank Roberto Cattelan of Veritas Laboratories for ICP-AES analyses, Michela Bruni for the help with halophytes' identification, and Mariangela Pasquon (ARPA FVG Udine) for DMA-80 $\mathrm{Hg}$ analyses.

\section{References}

Breckle SW. Salinity, halophytes and salt affected natural ecosystems. In "Salinity: environment-plants-molecules", edited by A. Lauchli, U. Luttge. Kluwer Academic Publishers, Dordrecht, the Netherlands; 2002:53-77.

Caçador I, Vale C, Catarino F. Accumulation of $\mathrm{Zn}, \mathrm{Pb}$, $\mathrm{Cu}$ and $\mathrm{Ni}$ in sediments between roots of the Tagus estuary salt marshes, Portugal. Est Coast and Shelf Sci 1996; 42:393-403.

Caçador I, Caetano M, Duarte B, Vale C. Stock and losses of trace metals from salt marsh plants. Mar Environ Res 2009; 67: 75-82.

Canário J, Vale C, Poissant L, Nogueira M, Pilote M, Branco V. Mercury in sediments and vegetation in a 
moderately contaminated salt marsh. (Tagus Estuary, Portugal). J Environ Sci 2010; 22:1151-1157.

Covelli S, Faganeli J, Horvat M, Brambati A. Mercury contamination of coastal sediments as the result of long-term cinnabar activity (Gulf of Trieste, northern Adriatic Sea). Appl Geochem 2001; 16:541-558.
Loring DH, Rantala RTT. Manual for the geochemical analyses of marine sediments and suspended particulate matter. Earth Sci Rev 1992; 32: 235-283.

Pethick J. An introduction to coastal geomorphology. Edward Arnold, London, 1984. 260 pp. 